\title{
PREFACE
}

\section{A Personal History}

My grandparents planted the hill behind their farmhouse in upstate New York, all the way to where the woods of maple, oak, and beech began, with dozens of apple varieties. Every fall the apples harvested from that orchard filled many barrels, and they were transformed into cider and apple pies all through the bitter winter. That was the story I was told. But my grandfather died in the woods above the orchard when a tree he and the hired men were cutting fell on him. My mother was a just a young girl, and my grandmother and her children struggled to keep up the farm, but as the children grew they were not much interested in farming, and most moved away to nearby towns. In my earliest boyhood memories of the orchard it was overgrown, thick with a jumble of native vegetation-blackberry brambles, elderberry trees, thistles, and grasses. By then the farm was becoming more of a memory than a real operation; there was not much left of its four barns, smokehouse, icehouse, dairy cattle, sheep, chickens, and fields of grain, hay, and tobacco.

In the summers I hacked paths through the dense vegetation under the wild, old unpruned apple trees, their branches broken by storms, some rotting and dying, others already dead, their dark limbs stark against the lush green of the hillside and the blue sky. I climbed the living apple trees too. My favorite was a Pound Sweet tree that produced huge golden-green apples full of sweet juice, a mid-nineteenth-century New England variety that I have never eaten or seen since.

I continued to visit the farm often after my family moved to the suburbs. Almost every drive back to visit brought new scenes of abandonment and decay of the agricultural landscape-barns and fields melting away to be replaced by housing developments. The stories my grandmother and great-aunts and great-uncles told of their own youth, growing up on farms, seemed more and more distant. I was witnessing the local reality of a massive national change in the structure of the U.S. agrifood system, a change that was happening in industrial countries around the world. From the first U.S. census of I840 until I935, the number of farms had been growing steadily, but with the rise of modern industrial agriculture, with its increased inputs and greater yields, small family farms were withering up and 
blowing away, and people were moving to cities. During the forty-three years between I935 and 1978 , U.S. agriculture changed dramatically_the number of farms declined 64 percent from its all-time peak of $6,8 \mathrm{I} 2,350$ to $2,478,642$, while the average farm size increased by I68 percent, from 63 to I68 ha (Hoppe and Banker 20I0:4, USDA NASS 20I2b).

My family was a part of that change; my grandparents were the last really rural generation. But food and how it is grown remained strong interests for me, and those interests, together with my time teaching in a secondary school in Zambia, central Africa, led me to graduate work at the University of Arizona, and to dissertation fieldwork in northeast Ghana. That fieldwork was part of a project investigating causes and responses to the Sahelian drought and the food shortages and famines that followed in its path (Cleveland I980), funded by the U.S. Agency for International Development (USAID) and conducted by the Ghanaian Council for Scientific and Industrial Research, based in Accra.

My fieldwork investigated the relationship between population dynamics and agriculture in the Kusasi village of Zorse, a farming community of about twenty-two hundred people spread over an area of about I8 $\mathrm{km}^{2}$ (fig. O.I). My year and a half of research included many interviews, observations, and measurements in 145 individual households (a 50 percent random sample) dispersed across the savanna, and it involved a lot of time moving between them. To expedite fieldwork I consolidated and repaired a few Polish bicycles from a dozen or so left in unusable condition by a previous project in the area, and I hired several research assistants, most from Zorse, who were bilingual in English and Kusaal, the language of the Kusasi.

On breaks from data collection I got to participate in the life of the village, helping in the fields of sorghum, millet, Bambara groundnut, sesame, okra, and other crops. Planting began with the rainy season, when the village turned from dusty brown to a sea of brightgreen fields. As soon as the shoots emerged, the race with the weeds was on. The weeds were mostly grasses that to me looked exactly like the millet and sorghum seedlings, because these crops are also grasses. I felt clumsy and ignorant when weeding in the fields alongside Kusasi farmers, and my muscles ached afterward. I felt awe and admiration for the farmers' skill in growing almost all the food they ate in the rocky soil using only fire, a short-handled hoe, and, in the case of a very few households, an ox-drawn plow.

During my time in Zorse, the importance of social relations in that farming community became more and more evident. They governed the formation of work parties, the allocation of land, and the regulation of livestock. One incident in particular impressed on me the social cohesion of the village. It was the dry season; the harvest was over and the fields had completed another cycle, shifting back from green to brown. We were pushing our bicycles along the top of a treeless ridge, studded with sharp chunks of granite, difficult terrain for a bicycle and likely to give you a flat tire if you dared to try riding. We trudged along under a hot, cloudless sky, colored beige with dust from the vastness of the Sahara, blown by the powerful Harmattan winds out of the northeast. From our vantage point I looked out over the landscape, dotted with leafless dawadawa, baobab, and other native trees, sentinels in the midst of the now-empty fields, trees left by farmers for their useful products. Dawadawa seedpods have a sweet, bright yellow pulp with a delicious flavor, and the seeds are proc- 


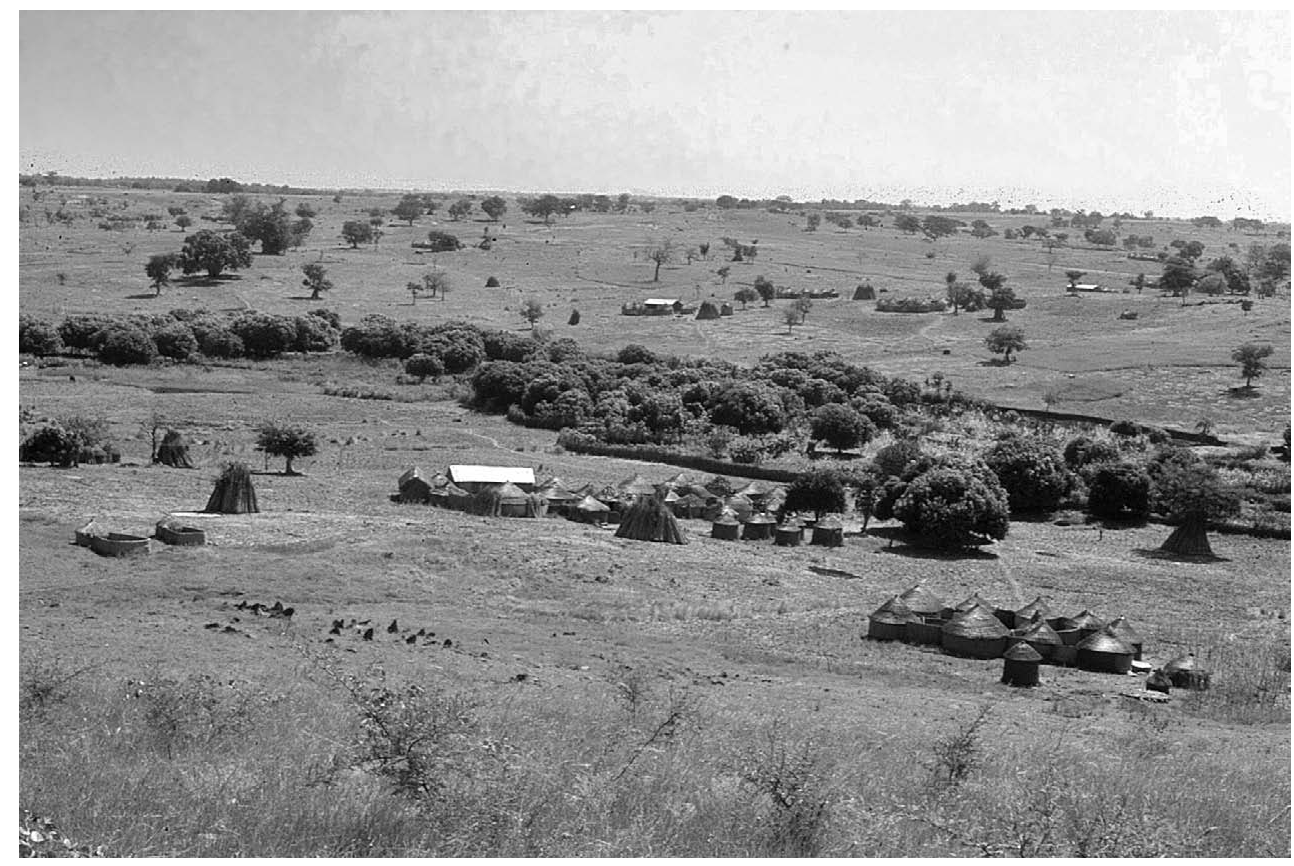

FIGURE 0.1. Zorse, Bawku, Ghana, in the dry season. The village is spread over the savanna landscape and consists of house compounds of round mud and stick structures with conical grass roofs and a few newer buildings with metal roofs. Compounds are surrounded by their most intensely managed fields, which are bare in the dry season. Also visible are bundles of 3-4 $\mathrm{m}$ sorghum stalks, economically important trees scattered in the fields, and walled dry season gardens following the course of a stream bed. Photo (C) David A. Cleveland.

essed into a dense, protein-rich substance that reminds me very much of miso made from soybeans and is used in soups and other dishes. Baobabs provide fresh green leaves for soup in April, when they leaf out before the rains begin, and when food supplies are running very low, with the first harvest of early millet still three months away. When the baobab fruits mature, kids puncture holes in the pods, each $15-20 \mathrm{~cm}$ long, add water, shake, and suck out the sweet-sour drink made by the dry, white matrix dissolving in the water. ${ }^{1}$

Resting with our bikes on that ridge, we looked out along the narrow, shallow brown valleys punctuated with splotches of green gardens filled with evergreen mangoes and citrus trees, sugarcane and vegetables, irrigated with water from shallow hand-dug wells. Next to the house compounds were soks, or shelters from the dry-season dust and wind, made by placing 4-meter-tall bundles of sorghum and millet stalks around the outside of a pole frame and across its top. The rainy season would bring a shift back to green, with the millet and sorghum growing everywhere, the native trees leafing out, and the compounds disappearing as the stalks of sorghum and millet towered over them.

Thinking about flat tires, about when the rains would start, and about needing to get as quickly as possible to the next household to do another set of interviews, I suddenly became 
aware of several scattered lines of people in the flat area below, about a half kilometer away. They were converging on the small cluster of mud-and-thatch compounds that included the one where I lived with the family of my chief field assistant, John Nbod. I stopped and asked John what was going on. He of course had already noticed the lines of people and had known immediately that they must be mourners coming to celebrate the death of an old woman who had been our neighbor, but whom I had seen only on one occasion because she was blind from onchocerciasis, a parasitic disease, and had leprosy, so she seldom left the confines of her room.

Later that night the celebration began with drinking, eating, dancing, and a trio of musicians playing traditional instruments. There was lots of dam, the earthy tasting, mildly alcoholic beer made from sprouted red sorghum grain, served in calabashes, rusty red with flecks of white, living yeast floating on it. Someone came up with an impromptu song about me- "There's a white man in our village" — and goaded me into joining the dance on the graves of those who had gone before the old woman with leprosy, lying in shallow holes beneath the giant baobab trees, graves shaped like wide-bottomed vases with a narrow neck open to the sky for the body to enter and sealed with an inverted clay pot.

Everyone sang and danced until the early hours of the morning. For the first time after nine months in the village, I felt more than superficially connected to the people, the soils, the crops, the food, the place, but most of all the community that was all of these together, this unique place in space and time. A small village in the savanna where generations of farmers had gained intimate knowledge of soils, plants, and weather patterns and had learned how to feed themselves. A village where increased population growth, spurred by the social changes brought by incorporation into the global economy, vaccinations, and roads seemed to be bringing a much more tenuous and uncertain future.

During two seasons of drought in this small village in the great east-west sweep of the savanna of West Africa I kept up my rigorous schedule of collecting quantitative data on farming, nutritional status, human fertility, mortality and migration, and labor allocation. Guilt and confusion flooded over me when I was greeted on the path with smiles and the stock phrase Com sabit ("Hunger is biting me") or when I doled out pieces of kulikuli (fried peanut paste) to the little children in the houses I visited to conduct interviews. I sought refuge in transforming the information from the interviews into the precise numbers in my data forms. Would the data I was gathering somehow help to increase understanding of the crisis in the human-nature relationship, help to make things better for these people whose survival here in the West African savanna sometimes seemed so precarious?

What my research was showing was that before European colonialists invaded and dominated Kusasi and other Ghanaian groups militarily, those groups had a system that was locally self-sufficient and provided some balance between population growth and food supply. The British colonialists' goal was to replace local self-sufficiency with integration into the global economy so that they could capture the benefits of local resources and labor. Kusasi were forced to migrate and work in the cacao farms, harbors, and mines in the southern part of Ghana (then under the colonial name of the Gold Coast). (I discuss the results of my research in Zorse further in chapter I.) 
As I lay awake at night in my mud-and-wattle hut, I felt there must be something drastically wrong with an agrifood system that rewarded hard work and insightful management not only with good harvests and joyful celebrations, in some years, but also with periodic famines, high infant death rates, and extensive degradation of soil, vegetation, and water resources. I tried to make sense of what I was learning from the people of Zorse. It didn't fit with the information I got from my infrequent trips to visit other researchers at the University of Science and Technology in Kumasi and from government and international development professionals in the capital, Accra (Cleveland I990). I was frustrated by my ignorance about how to reconcile the conflicting views of the situation held by Kusasi farmers and by these experts.

From the perspective of most of these experts, the problem was that Kusasi and other small-scale African farmers were "backward" and needed to modernize, to catch up with the rest of the world by using more inputs such as manufactured fertilizer and seeds of modern crop varieties. And if they could not do that, they needed to leave their traditional farming and move to work as laborers on larger farms or in nonfarming jobs elsewhere. It seemed in some ways like a newer version of the colonial agenda. Indeed, the agricultural initiative in Africa today that receives the most funding is the Alliance for a Green Revolution in Africa (AGRA) and its associated programs, funded by industrial world governments, foundations, and agribusiness corporations, whose agenda seems in many ways like a high-speed version of those of the colonial era and of my time in Ghana (AGRA 20I2).

The perspective of most Kusasi farmers was quite different; they were proud of their skills and accomplishments, and they were carrying on the farming, religious, and social life of their ancestors. Still, the hard work of farming and the uncertainty of their harvests in some years made them ready for changes that would improve their lives yet not require that they relinquish control of them. But what possibilities were there in a world changed irrevocably in the last several generations? As the situation became more and more difficult, many people were leaving Zorse. These included young people seeking education, some of whom ended up working as veterinarians or researchers or administrators, not only in Ghana but in countries around the world.

After returning to the United States from Ghana and finishing my dissertation, I had the opportunity to collaborate with ethnoecologist Daniela Soleri on work with Hopi and Zuni farmers in the southwestern United States and with Zapotec farmers in Oaxaca, Mexico. Their situation was much like that of the Kusasi. Native Americans had been farming throughout most of the North and South American continents for generations. In the United States, almost all native farming and food had been exterminated by Europeans, along with many of the tribes themselves. A very small number of tribes, such as the Hopi and Zuni, were able to survive, along with many of their crop varieties, foods, and farming traditions (Cleveland, Bowannie, et al. I995, Soleri and Cleveland I993), only because most Europeans considered their arid high desert land unfit for farming compared with the fertile valleys they stole from the less fortunate tribes. In Mexico, traditional small-scale farmers faced more and more difficult economic conditions under increasingly unfriendly neoliberal 
economic policies, such as the North American Free Trade Agreement (NAFTA) (Fox and Haight 20I0).

It is a long drive north from Tucson, where we were based, before the turnoff onto Arizona State Route 264 running east-west through the high mesa country of Hopi land. It is easy to look past the sandy, scrub-covered terrain that lies beyond the side of the road. Every so often a pickup truck has pulled off the road, no one around, nothing that would seem to be a reason for stopping. But if you do stop, and take the time to walk away from the road until you can get a view down the slope beyond, chances are you will see a Hopi farmer, or farm family, checking on their sandy field-a field filled with scattered, dense bundles of long, bright-green leaves. This is a Hopi maize field. ${ }^{2}$ Hopis, and their neighbors, the Zuni and Acoma, have been growing maize in fields like this for at least two thousand years.

When Daniela and I worked at Hopi, farmers invited us to join them in their fields-it was a lot easier for all of us than asking them to answer our questions while sitting in their houses. We saw firsthand that Hopi maize fields are not scattered at random over the landscape. Hopi, Zuni, and other farmers in the area learned through many generations to plant where the scrub-covered slopes indicate water drainage that brings the snowmelt and later the runoff from summer rains to their maize plants, along with nutrients in organic matter and minerals (Norton et al. 2007). Water is held in the fields by a deep layer of heavy, clayey soil, and the thick sandy layer above acts as a mulch, slowing down loss of that water by evaporation. Seeds are planted with a digging stick, traditionally made of greasewood but now often made of other materials, such as recycled crankshafts (fig. o.2). Farmers use the sticks to scoop out narrow holes $30 \mathrm{~cm}$ and more below the surface where the clayey layers begin, layers that have trapped the runoff of the melting snow. Farmers place the seeds there, and then replace the soil, in the same order as it was removed-the moister, cooler, clayey soil next to the seeds, the warm, dry, sandier soil on the surface.

For generations Hopi and Zuni farmers succeeded in feeding their families and communities in some of the most arid agricultural conditions in the world. Among other things, they developed farming methods, selected crop populations, organized their labor and other resources, and devised storage techniques that made this success possible. Today these farmers struggle to find ways of keeping their agriculture, food, language, and culture alive, even while they are surrounded by and often participate successfully in the larger society around them, including the huge cattle ranches and the cotton, alfalfa, and vegetable fields of the mainstream agrifood system.

This highly industrial, mainstream agriculture contrasts with traditional Hopi and Zuni agriculture in the inputs used, crops grown, and methods deployed, although both are labor intensive (Khan, Martin, et al. 2004). In the orchards, vineyards, and fields of vegetables of the U.S. south and west it is common to see farm workers stooped over, weeding, thinning, or picking, seeming out of place in the large-scale landscape-factories in the field (McWilliams 2000 [1939]). They are there instead of in their own fields and pueblos in Mexico and Central America because of the money they can earn. For some it is an adventure, and for 


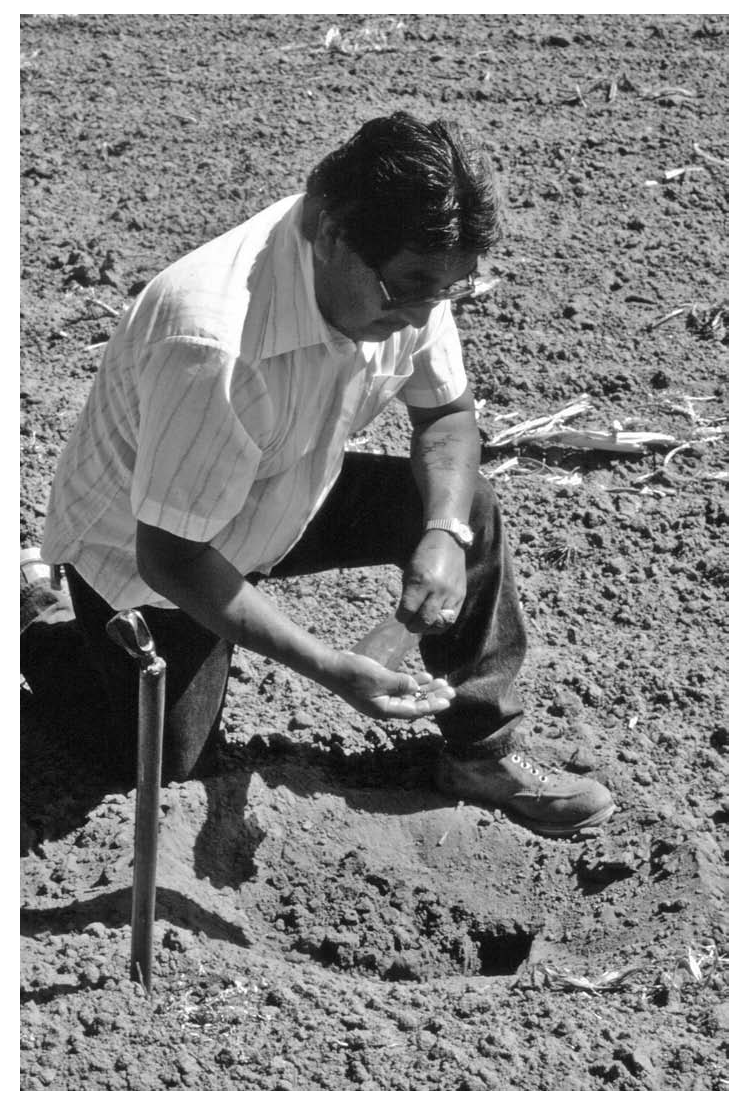

FIGURE 0.2. Hopi farmer Jerry Honawa planting bean seed. The order of layers of soil removed from the planting hole has been preserved; soil layers will be returned to the hole in that order. Photo (C) Daniela Soleri. Used with permission of photographer and subject.

others it is a sacrifice they make reluctantly, leaving their families and communities for a foreign land.

The home of many of the people who work in the fields of Arizona and California is southern Mexico, including the state of Oaxaca. In the middle of a summer with good rains, the Valley of Oaxaca, at I,500 meters above sea level, is a huge bowl of green maize plants. Maize was first domesticated about $350 \mathrm{~km}$ from here nearly nine thousand years ago, and some of the oldest known cobs of early maize were found mere kilometers from where we worked. Today maize is still revered throughout Mexico, and there is rapidly growing interest in Mexico City and other urban areas in traditional foods made from traditional varieties of maize (Soleri, Cleveland, and Aragón Cuevas 2008), of which there are hundreds in Mexico (AragónCuevas et al. 2006, Wellhausen et al. I952). The farming families we became friends with in Oaxaca take special pride in the foods they make with the maize they grow on their farms and sometimes grind by hand on a metate-including tejate, a refreshing drink made from maize, cacao, and other ingredients, a version of which has likely been drunk in Oaxaca for millennia (Soleri, Cleveland, and Aragón Cuevas 2008, Sotelo et al. 2012).

Yet after hundreds of generations, a way of life seems to be vanishing. Many Zapotec farmers have a deep sadness from their sense of having no control of the change, no good 
choices. They are caught between trying to grow enough food to stay alive in their homes or abandoning the villages of their ancestors — the soil, the maize, the mountains they loveand migrating to Mexico City or El Norte, the United States, some of them to work in the industrial agriculture fields. There are Oaxacan villages where most of the working-age women and men are migrants, gone for much of the year, or for several years at time, or even permanently, breaking the chain of knowledge about how to plant maize, save seeds, make tejate. Recently this trend is changing due to factors in both the United States and Mexico; it remains to be seen whether this will also result in slowing the shift away from farming by small-scale farmers in Mexico, which has been going on for many decades.

It is not only large-scale industrialized agribusiness that relies on a noncompetitive, mostly migrant labor supply. Small-scale farmers in California, who are part of a national movement in the United States to localize the food system, are also often dependent on migrant workers from villages in Oaxaca and other places in southern Mexico and Central America. Alternative ways of growing food, such as "organic," are even more labor intensive, for example, because they have to control weeds mechanically, including by hand, instead of using herbicides (Shreck et al. 2006). Shoppers at farmers' markets buying "fresh and local" are for the most part unaware of the long, arduous hours of work that produce the bounty on offer, or of the effect on the home communities of the migrants who do that work.

Many in the grassroots local food movement believe that localization is the best solution to the problems caused by the mainstream global agrifood system. In Santa Barbara County, where I live, local food is booming, as it is in much of the rest of the United States. Yet the system is still largely a centralized export-import business-Santa Barbara County produces more than ten times the fruits and vegetables it consumes, yet 99 percent of this production is exported, while over 95 percent of the produce consumed in the county is imported (Cleveland et al. 20IIb).

A major challenge to localization is that most produce and other food is sold through national supermarket and hyper store chains. One of the most heated arguments about local food is whether the large corporations that control the current system can contribute to localization, or whether their involvement in the movement will co-opt and destroy it. What does it mean when global retailers such as Walmart - the largest food retailer globally and with a bad reputation among local food advocates, community groups, and labor unions-promotes sustainable agriculture, local food, or better nutrition (Huber 20II)? When Will Allen's organization Growing Power, a star in the U.S. local food movement, accepted a large donation from Walmart it generated much controversy and soul searching (e.g., Fisher 20II).

Debates about our agrifood system and what direction it should be moving in are often dominated by a contrast between supporters of the dominant mainstream, global industrial system and supporters of a variety of alternatives, which are often smaller in scale and focused more on environmental and social issues and less on economic issues. The current world food crisis that began in 2007-2008 has intensified these debates, highlighting the contrast between the I5 percent of the world's poor who are chronically hungry and the excessive consumption of the rich. So has the biggest environmental crisis of our time, per- 
haps of all human history-global climate warming. Agriculture is not only one of the largest causes of global warming and other environmental problems but will also suffer the negative consequences of this change.

My experiences and research-from the family farm in upstate New York to the villages in West Africa; from Hopi, Zuni, and Oaxaca to Santa Barbara-have led me to believe that learning to identify and analyze these perspectives, and the data and values they are based on, can empower us to participate in creating a better future. For example, to discuss localization we first have to agree on whose definition to use. Even if we agree on a definition, we will need to figure out how local an agrifood system is by measuring some sort of indicator, such as food miles. Food miles have become a popular localization indicator, yet often they may not accurately reflect the goals of localization-which include greater profits, improved nutrition, environmental stewardship, and food justice-as my students and I found in our research in Santa Barbara, discussed in more detail in chapter 9 (Cleveland et al. 20Irb).

In these debates, sorting out the data used and the assumptions made from different perspectives is essential, but not easy. How can we do this? In this book I present one way, using key concepts to make sense of the range of data and opinions about our agrifood systems and the dramatically different ideas about how they should change. 
This page intentionally left blank 